\title{
Natural Inhibitors of Pancreatic Lipase as New Players in Obesity Treatment
}

Authors

Affiliation
Ana Laura de la Garza, Fermín I. Milagro, Noemí Boque, Javier Campión, J. Alfredo Martínez

Department of Nutrition and Food Sciences, Physiology and Toxicology, University of Navarra, Pamplona, Spain
Key words

- Orlistat

- high fat diet

- polyphenols

- saponins

obesity

- fat digestion received Dec. 7, 2010

revised February 11, 2011

\section{Bibliography}

Dol http://dx.doi.org/ 10.1055/s-0030-1270924 2011

(c) Georg Thieme Verlag KG

ISSN 0032-0943

\section{Correspondence}

Prof. J. Alfredo Martinez

Department of Nutrition

and Food Sciences,

Physiology and Toxicology

University of Navarra

c/Irunlarrea 1

31008 Pamplona

Spain

Phone: +34948425600

Fax: + 34948425649

jalfmtz@unav.es accepted February 21, 2011

Published online March 16,

Planta Med 2011; 77: 773-785

Stuttgart · New York .

\section{Abstract}

$\nabla$

Obesity is a multifactorial disease characterized by an excessive weight for height due to an enlarged fat deposition such as adipose tissue, which is attributed to a higher calorie intake than the energy expenditure. The key strategy to combat obesity is to prevent chronic positive impairments in the energy equation. However, it is often difficult to maintain energy balance, because many available foods are high-energy yielding, which is usually accompanied by low levels of physical activity. The pharmaceutical industry has invested many efforts in producing antiobesity drugs; but only a lipid digestion inhibitor obtained from an actino-

\section{Introduction}

\section{$\nabla$}

Obesity is becoming one of the greatest threats to global health in this century, with more than 1.5 billion overweight adults and at least 400 million of clinically obese subjects [1]. Due to these increasing obesity rates, the World Health Organization (WHO) has prompted to consider it as the epidemic of XXI century and to promote strategies to prevent and control its progress [2].

The development of obesity is characterized by a chronic imbalance between energy intake and energy expenditure [3-5], and it is often ascribed to changing lifestyles and inadequate dietary habits [3]. Also, decreased energy expenditure is often associated with an inherited low basal metabolic rate, low energy cost of physical activity, and low capacity for fat oxidation [6]. To reduce body weight and adiposity, a change in lifestyle habits is still the crucial cornerstone [7]. Physical activity might be helpful in the prevention of obesity by elevating the average daily metabolic rate and increasing energy expenditure [3]. Unfortunately, this clinical approach is not long-term lasting, and weight regain is often seen. Drugs that bacterium is currently approved and authorized in Europe for obesity treatment. This compound inhibits the activity of pancreatic lipase, which is one of the enzymes involved in fat digestion.

In a similar way, hundreds of extracts are currently being isolated from plants, fungi, algae, or bacteria and screened for their potential inhibition of pancreatic lipase activity. Among them, extracts isolated from common foodstuffs such as tea, soybean, ginseng, yerba mate, peanut, apple, or grapevine have been reported. Some of them are polyphenols and saponins with an inhibitory effect on pancreatic lipase activity, which could be applied in the management of the obesity epidemic. prevent weight regain appear necessary in obesity treatment [7]. Thus, the development of natural products for the treatment of obesity is a challenging task, which can be launched faster and cheaper than conventional single-entity pharmaceuticals [8]. Many medicinal plants may provide safe, natural, and cost-effective alternatives to synthetic drugs $[9,10]$. Currently, one of the most important strategies in the treatment of obesity includes development of inhibitors of nutrient digestion and absorption. For example, acarbose is an antidiabetic drug that inhibits glycoside hydrolases, thus preventing the digestion of complex carbohydrates and decreasing postprandial hyperglycemia $[11,12]$. Similar compounds with alpha-amylase inhibiting activity that can be used for diabetes control are being isolated from different plants. The list includes valoneaic acid dilactone [13], obtained from banaba (Lagerstroemia speciosa), the ethanol extract obtained from chestnut astringent skin [14], or the purified pancreatic alpha-amylase inhibitor isolated from white beans (Phaseolus vulgaris), which is able to reduce glycemia in both nondiabetic and diabetic rats [15]. 
In this context, since dietary lipids represent the major source of unwanted calories, the inhibition of fat digestion is an interesting approach for reducing fat absorption [16]. Orlistat is the only authorized antiobesity drug in Europe and has been shown to act through inhibition of pancreatic lipase (PL), which is a key enzyme for the digestion of dietary triglycerides [17]. Orlistat is the saturated derivative of lipstatin, an inhibitor of PL isolated from the bacterium Streptomyces toxytricini [18]. This molecule exerts a modest weight lowering effect when accompanying a suitable dietary advice. Thus, in a recent meta-analysis [19], the mean BMI change with Orlistat (120 mg three times daily) was a reduction of $0.83 \mathrm{~kg} \mathrm{~m}^{-2}$ (95\% CI: $0.47-1.19$ ) compared with placebo. Accompanying this antiobesity action, Orlistat is also able to modestly reduce blood pressure, improve oral glucose tolerance and prevent the onset of type 2 diabetes [20,21].

Now, extracts from hundreds of species of medicinal plants, vegetables, and fruits [22] as well as products from microorganisms [9], fungi [23] and marine algae [24] are being screened for potential lipase inhibitory activity. Ideally, these treatments will be viewed as adjuncts to behavioral and lifestyle changes aimed at maintenance of weight loss and improved health [8].

\section{Obesity and High-Fat Diets}

$\nabla$

Epidemiological studies have shown a direct relation between the incidence of overweight/obesity and dietary fat consumption $[3,6,25]$.

Humans are frequently exposed to fat rich foods, which are usually associated with a high-energy intake $[6,26]$. Thus, those foods with a high-energy and dietary fat content are considered to promote body fat storage and weight gain in humans [8]. One explanation is that, in commercially available food items, the percentage of energy derived from fat is highly correlated with energy density. Given that fat contains $9 \mathrm{kcal} / \mathrm{g}$ compared with $4 \mathrm{kcal} / \mathrm{g}$ for carbohydrates and proteins, foods rich in fat are often high in energy density. Thus, when a similar volume of food is consumed, energy intake will be higher in high-fat diets compared with low-fat diets [3].

On the other hand, independently of an increased energy intake, specific dietary constituents may promote the development of obesity. This statement means that even consuming an equal amount of energy, the diet composition is important, especially the balance between nutrients $[27,28]$.

Thus, a macronutrient profile (high-protein, high-carbohydrate, and high-lipid diets) can affect diet-induced thermogenesis, the oxidation pathway, energy intake, gene expression, or the level of some hormones [29]. Following a high-fat diet, the diet-induced thermogenesis is lower than following high-protein and carbohydrate diets, and also fat is more effectively absorbed from the gastrointestinal tract than are carbohydrates, which translates into lower energy expenditure when following a high-fat diet [26]. So, high-fat diets produce a metabolically more efficient state, at least in part because of the lower postprandial thermogenic effect of lipids in comparison with carbohydrates [30].

Furthermore, the consumption of a high-fat diet has the capacity to modulate the gastrointestinal responses to ingested fat and, thereby, may lead to impairments in appetite regulation that favour the development of obesity. Dietary fat usually implies an increase in energy consumption because it has a lower potential for inducing satiety than carbohydrates and protein $[6,31]$.
Hence, high-fat diets may play an important role in the increased prevalence of obesity and can be a triggering factor in the development of hyperglycemia and hyperinsulinemia [3,32]. Moreover, the intake of dietary fats is usually accompanied by a higher intake of refined sweet carbohydrates (fast food, desserts), where the high intake of sucrose promotes weight gain, visceral adiposity, and the development of diseases that are related with obesity, such as diabetes and cardiovascular diseases [33]. Therefore, lowfat diets often are prescribed in the prevention and treatment of overweight and obesity because a reduction in dietary lipids without restriction of total energy intake could cause weight loss [26].

\section{Fat digestion}

Recent studies indicate that fat digestion is a prerequisite for the effects of fat on gastric emptying, gastrointestinal hormone secretion, appetite, and energy intake [6]. An increasing number of gastrointestinal enzymes involved in nutrient digestion are being identified and characterized, representing a rich pool of potential therapeutic targets for obesity and other metabolic disorders [9]. Especially interesting are those enzymes that are related with dietary fat, which includes pre-duodenal lipases (lingual and gastric lipases), pancreatic lipase (PL), cholesterol-ester lipase, and bile-salt stimulated lipase [34].

Most dietary fat is ingested as triglycerides (90-95\%), and their hydrolysis starts in the mouth, then goes on through the stomach by an acid stable gastric lipase, and continues in the duodenum through the synergistic actions of gastric and colipase-dependent pancreatic lipases (PL), leading to the formation of monoglycerides and free fatty acids (FFA) ( $\bullet$ Fig. 1). FFA are absorbed by the enterocyte to synthesize new triglyceride molecules, which are transported to the different organs via lipoproteins, especially chylomicrons, after a meal [34].

Pancreatic lipase (PL), encoded by the PNLIP gene in humans, plays a key role in the efficient digestion of triglycerides [35]. It is secreted into the duodenum through the duct system of the pancreas and is responsible for the hydrolysis of $50-70 \%$ of total dietary fats [9]. This enzyme has been widely used for the determination of the potential efficacy of natural products as antiobesity agents [36].

Orlistat is currently the only clinically approved drug for obesity management in Europe. This molecule acts by inhibiting PL activity and the reduction of triglyceride absorption, and its long-term administration accompanying an energy restricted diet, results in weight loss [37]. Reduction on intestinal lipid digestion has been related to a decrease in the intra-abdominal fat content [7]. Thus, this compound is associated with a small, but statistically significant weight loss of about 3\% more than diet alone in overweight and obese people [1]. In addition to losing weight, Orlistat within a prescribed diet has been shown to be safe and more effective than diet alone in modifying some of the risk of coronary artery disease and other obesity-related comorbidities. The most commonly reported adverse effects of Orlistat are a range of gastrointestinal side effects, including steathorrhea, bloating, oily spotting, fecal urgency, and fecal incontinence, as well as hepatic adverse effects $[19,38]$. These adverse effects are similar to those observed for other lipase inhibitors tested in phase II studies, such as Cetilistat (ATL-962) [39].

On the other hand, the inhibition of fat absorption could be accompanied by fat-soluble vitamin deficiencies, which could be prevented by the vitamin supplementation strategy, as other au- 


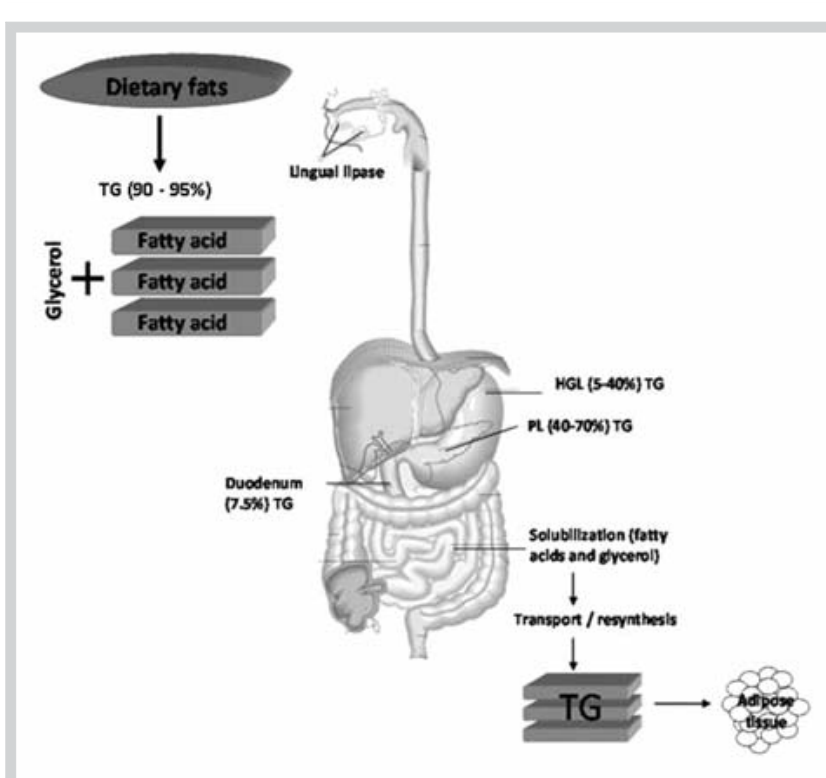

Fig. 1 Fat metabolism in humans. Dietary fats are hydrolyzed in the gastrointestinal tract, where some lipases are involved.

thors have recommended when vitamin deficiency occurs in patients undergoing Orlistat therapy [40].

Hence the interest in the search for new natural substances that show potent inhibitory activity against PL and have fewer side effects than the current ones.

\section{Natural inhibitors of pancreatic lipase \\ $\nabla$}

In the continued search for effective antiobesity agents, several bacterial, fungal, and marine species have been screened to find new compounds with PL inhibitory activity.

Many metabolic products from microorganisms, such as different kinds of Streptomyces (toxytricini, sp. NR 0619, albolongus, aburaviensis, and lavendulae) have a potent inhibitory activity of PL [9]. Lipstatin was isolated from an actinobacterium, Streptomyces toxytricini, and the catalytic hydrogenation product of lipstatin is the approved antiobesity drug tetrahydrolipstatin (Orlistat; marketed by Roche as Xenical ${ }^{\mathrm{TM}}$ ) [18]. Panclicins, analogs of tetrahydrolipstatin isolated from Streptomyces sp. NR0619, also present strong anti-lipase activity [41]. Other compounds which also act as potent inhibitors of PL, at least in vitro, are ebelactones A and B, isolated from Streptomyces aburaviensis [42], and vibralactone, isolated from the culture broth of the polypore Boreostereum vibrans [43]. Finally, other examples of lipase inhibitors have been obtained from yeasts and fungi such as Candida antarctica, Candida rugosa, Gestrichum candidum, Humicola lanuginose, and Pseudomonas glumae, which have received special attention and are widely used in the pharmaceutical industry [44].

Due to the biodiversity and unexplored resources, the fungal kingdom has been particularly searched to find new substances with lipase inhibitory activity. In a thorough screening of lipase inhibitors of fungal origin in Slovenia [23], extracts obtained from three species, Laetiporus sulphureus, Tylopilus felleus, and Hygrocybe conica, exhibited very high lipase inhibitory activities (83\% $\pm 5 \%, 96 \% \pm 3 \%$, and $97 \% \pm 5 \%$, respectively), even higher than Orlistat. Pleurotus eryngii water extract also shows a significant in- hibitory activity against PL, preventing postprandial hyperlipidemia through low intestinal absorption of dietary fat [45]. Finally, the water and ethanol extracts from fruiting bodies of Phellinus linteus show a potent lipase inhibitory and antiobesity effect [46]. A special case is that of monascus pigments from Monascus $s p$., which have been used for many years as natural colorants and as a healthy food in East Asia, being employed in the production of certain fermented foods. Various monascus derivatives with incorporated unnatural amino acids show inhibitory activities against lipase [47].

In the same way, marine products are an especially rich source of bioactive compounds [48]. In a milestone study, Bitou et al. [24] screened the lipase inhibitory activities of methanol and ethyl acetate extracts from 54 species of marine algae. These investigations observed a very high activity (almost $100 \%$ inhibition) in the methanol extracts from Caulerpa taxifolia and Asparagopsis tociformis, although the methanolic extracts of other Chlorophyta (i.e., Caulerpa okamurae or Codium latum), Rhodophyta (i.e., Gloiopeltis tenax or Hypnea charoides), and Phaeophyta (i.e., Sargassum muticum, Dictyopteris latiuscula, or Cutleria cylindrica), were also very promising. In this sense, Phaeophyta generally contains large amounts of polyphenols, such as tannins, with lipase-inhibiting activity. In fact, most compounds with a porphyrin structure are able to inhibit lipase activity [49]. Two algae whose extracts inhibit gastric and pancreatic lipases are Caulerpa prolifera, which may be a source of a potential antiobesity agent [50], and Caulerpa taxifolia, which synthesizes the toxin caulerpenyne [24]. On the other hand, carotenoids from Undaria pinnatifida and Sargassum fulvellum, specifically fucoxanthin that is metabolized in vivo to fucoxanthinol, suppress triglyceride absorption via the inhibition of PL in the intestinal lumen [51]. Medicinal plants have been used as dietary supplements for body weight management and control in many countries. In this sense, presence of PL inhibitors has been demonstrated in different plant species ( Table 1), although more research is needed for identifying and characterizing effective lipase inhibitors [52]. Lipase inhibitors of plant origin include certain proteins, such as those from soybean [53] and from wheat bran and germ [54]. Other proteins that strongly inhibit hydrolysis of triglycerides are the basic protein protamine [55] and $\varepsilon$-polylysine [56], which could act, as several amphiphilic proteins like ovoalbumin and $\beta$ lactoglobulin [57], by the desorption of lipase from its substrate due to a change in interfacial quality [58].

Other lipase inhibitors from plant origin are basic polysaccharides, especially chitosan oligosaccharides, water-soluble chitosan (46 kDa) and polydextrose when a basic group is introduced $[59,60]$, phytic acid and other myoinositol phosphate esters [61], phenylboronic acid, a potent inhibitor of lipase from Oryza sativa [62], and carnosic acid, a diterpene isolated from the methanolic extract of the leaves of sage (Salvia officinalis) and rosemary [63]. Korean and Chinese researchers have been very active in the search of new lipase inhibitors of herbal origin. Among the most promising compounds, there are platycodin $\mathrm{D}$, isolated from the fresh roots of Platycodon grandiflorum [64,65], dioscin from Dioscorea nipponica [66], licochalcone A from the roots of Glycyrrhiza uralensis [67], phenolic constituents from the leaves of Nelumbo nucifera [68], the aqueous ethanol extracts of Juniperus communis or common juniper (bark) and Illicium religiosum (wood) [69], the ethanol extract from stem bark and leaves from mango tree (Mangifera indica), which is able to prevent weight gain induced by feeding a high-fat diet to Wistar rats [70], a pomegranate leaf extract rich in ellagic acid and tannins [71], Rhei rhizoma 
Table 1 Plant extracts that showed over $40 \%$ inhibitory activity in vitro of pancreatic lipase and part of the plant from which the extract has been isolated.

\begin{tabular}{|c|c|c|c|c|c|c|c|c|c|}
\hline Family & Scientific name & $\begin{array}{l}\text { Common } \\
\text { name }\end{array}$ & $\begin{array}{l}\text { Part } \\
\text { of plant }\end{array}$ & Ref & Family & Scientific name & $\begin{array}{l}\text { Common } \\
\text { name }\end{array}$ & $\begin{array}{l}\text { Part } \\
\text { of plant }\end{array}$ & Ref \\
\hline Aeraceae & $\begin{array}{l}\text { Acer pseudosiebol- } \\
\text { dianum }\end{array}$ & Korean maple & Whole & [138] & Lamiaceae & Spirodela polyrhiza & $\begin{array}{l}\text { Common } \\
\text { duckmeat }\end{array}$ & Whole & [138] \\
\hline Anacardiaceae & Pistacia vera & Pistachio & Fruits hull & [52] & Lamiaceae & Thymus pulegoides & Lemon thyme & Whole & [22] \\
\hline Apiaceae & Levisticum officinale & Garden lovage & Whole & [52] & Lauraceae & $\begin{array}{l}\text { Cinnamomum } \\
\text { zeylanicum }\end{array}$ & Cinnamon & Derm & [52] \\
\hline Apiaceae & Sanicula chinensis & Bian Dou Cai & Whole & [138] & Lauraceae & Lindera glauca & $\begin{array}{l}\text { Grayblue } \\
\text { spicebush }\end{array}$ & Whole & [138] \\
\hline Araliaceae & $\begin{array}{l}\text { Eleutherococcus } \\
\text { senticosus }\end{array}$ & Siberian ginseng & Leaves & [114] & Liliaceae & $\begin{array}{l}\text { Asparagus } \\
\text { cochinchinesis }\end{array}$ & Shiny asparagus & Radix & [138] \\
\hline Aspidiaceaes & Cyrtomium falcatum & Japanese holly fern & Whole & [138] & Liliaceae & Scilla scilloides & Chinese scilla & Whole & [138] \\
\hline Asteraceae & Artemisia scoparia & $\begin{array}{l}\text { Redstem } \\
\text { wormwood }\end{array}$ & Whole & [138] & Linaceae & $\begin{array}{l}\text { Linum } \\
\text { usitatissimum }\end{array}$ & Oil flax & Seed & [139] \\
\hline Asteraceae & Helianthus annus & $\begin{array}{l}\text { Common } \\
\text { sunflower }\end{array}$ & Seed & [139] & Lythraceae & Lythrum salicaria & $\begin{array}{l}\text { Purple } \\
\text { loosestrife }\end{array}$ & Whole & [138] \\
\hline Brassicaceae & Brassica nigra & Black mustard & Radix & [22] & Musaeae & Musa sapientum & French plantain & Fructus & {$[22]$} \\
\hline Brassicaceae & $\begin{array}{l}\text { Brassica oleracea } \\
\text { capitata }\end{array}$ & Cabbage & Folium & [22] & Myricaceae & Myrika spp & Bayberry & Bark & [140] \\
\hline Brassicaceae & Raphanus sativus & Radish & Radix & [22] & Myrtaceae & Myrtus communis & True myrtle & Leaves & [52] \\
\hline Caprifoliaceae & Lonicera japonica & $\begin{array}{l}\text { Japanese honey- } \\
\text { suckle }\end{array}$ & Whole & [138] & Myrtaceae & Solanum tuberosum & Potato & Flowers & {$[22]$} \\
\hline Celastraceae & $\begin{array}{l}\text { Euonymus } \\
\text { sachalinensis }\end{array}$ & Spindletree & Whole & [138] & Oleaceae & Olea europeae & Olive & Folium & {$[22]$} \\
\hline Crassulaceae & Rhodiola rosea & $\begin{array}{l}\text { Roseroot } \\
\text { stonecrop }\end{array}$ & Whole & [141] & $\begin{array}{l}\text { Orchida- } \\
\text { ceae }\end{array}$ & Gastrodia elata & Tien Ma & Whole & [138] \\
\hline Cucurbitaceae & Cucurbita pepo & Field pumpkin & Whole & [138] & Oxalidaceae & Oxalis corniculata & $\begin{array}{l}\text { Sleeping } \\
\text { beauty }\end{array}$ & Whole & [138] \\
\hline Cucurbitaceae & $\begin{array}{l}\text { Momordica } \\
\text { cochinchinensis }\end{array}$ & $\begin{array}{l}\text { Spiny } \\
\text { bittergourd }\end{array}$ & Whole & [138] & Poaceae & Eriochloa villosa & $\begin{array}{l}\text { Hairy cup- } \\
\text { grass }\end{array}$ & Whole & [138] \\
\hline Cyperaceae & Bulbostylis barbata & Watergrass & Whole & [138] & Poaceae & Hemarthria sibirica & Weed & Whole & [138] \\
\hline Cyperaceae & Carex kobomugi & $\begin{array}{l}\text { Japanese } \\
\text { sedge }\end{array}$ & Whole & [138] & Poaceae & $\begin{array}{l}\text { Panicum dichotomi- } \\
\text { florum }\end{array}$ & $\begin{array}{l}\text { Fall panic- } \\
\text { grass }\end{array}$ & Whole & [138] \\
\hline Cyperaceae & Cyperus amuricus & $\begin{array}{l}\text { Asian } \\
\text { flatsedge }\end{array}$ & Whole & [138] & Poaceae & Setaria italica & $\begin{array}{l}\text { Foxtail bris- } \\
\text { tlegrass }\end{array}$ & Whole & [138] \\
\hline Eleagnaceae & $\begin{array}{l}\text { Elaeagnus macro- } \\
\text { phylla }\end{array}$ & Oleaster & Whole & [138] & $\begin{array}{l}\text { Polygala- } \\
\text { ceae }\end{array}$ & Polygala tenuifolia & Yuan Zhi & Whole & [138] \\
\hline Ericaceae & Arctostaphylos uva-ursi & Bear berry & Folium & [22] & $\begin{array}{l}\text { Polygona- } \\
\text { ceae }\end{array}$ & Reynoutria elliptica & $\begin{array}{l}\text { Black bind- } \\
\text { weed }\end{array}$ & Whole & [138] \\
\hline Ericaceae & Vaccinium myrtillus & Bilberry & Fructus & [22] & $\begin{array}{l}\text { Polygona- } \\
\text { ceae }\end{array}$ & Rheum ribes & Rhubarb & $\begin{array}{l}\text { Rhi- } \\
\text { zomes }\end{array}$ & {$[52]$} \\
\hline Eriocaulaceae & $\begin{array}{l}\text { Eriocaulon siebol- } \\
\text { dianum }\end{array}$ & $\begin{array}{l}\text { Flattened } \\
\text { pipewort }\end{array}$ & Whole & [138] & $\begin{array}{l}\text { Potamogetona- } \\
\text { ceae }\end{array}$ & Potamogeton distinctus & Pondweed & Whole & [138] \\
\hline Fabaceae & Alhagi camelorum & Camelthorn & $\begin{array}{l}\text { Aerial } \\
\text { parts }\end{array}$ & [52] & Rosaceae & Rosa damascene & Damask rose & Floret & {$[52]$} \\
\hline Fabaceae & Glycyrrhiza uralensis & Gan Cao & Whole & [138] & Rosaceae & Rubus idaeus & Raspberry & Fructus & {$[22]$} \\
\hline Fabaceae & Lespedeza cuneata & $\begin{array}{l}\text { Chinese bush } \\
\text { clover }\end{array}$ & Whole & [138] & Rosaceae & Malus domestica & Apple & Fructus & {$[22]$} \\
\hline Fabaceae & Phaseolus vulgaris & Common bean & Whole & [22] & Rubiaceae & $\begin{array}{l}\text { Gardenia jasmi- } \\
\text { noides }\end{array}$ & $\begin{array}{l}\text { Cape jas- } \\
\text { mine }\end{array}$ & Whole & [138] \\
\hline Fabaceae & Pisum sativum & Garden pea & Fructus & [22] & Rubiaceae & Rubia akane & $\begin{array}{l}\text { Asian mad- } \\
\text { der }\end{array}$ & Whole & [138] \\
\hline Fabaceae & Pueraria thunbergiana & Kudzu & Whole & [138] & Rutaceae & Citrus aurantifolium & Lime & Whole & [138] \\
\hline Fabaceae & Quercus infectoria & Aleppo oak & Galls & [52] & Rutaceae & Murraya koeninggi & $\begin{array}{l}\text { Curryleaf } \\
\text { tree }\end{array}$ & Leaves & [142] \\
\hline Juncaceae & Juncus effusus & Soft rush & Whole & [138] & Rutaceae & Orixa japonica & Pearl frost & Whole & [138] \\
\hline Lamiaceae & Agastache rugosa & $\begin{array}{l}\text { Purple giant } \\
\text { hyssop }\end{array}$ & Whole & [138] & Saxifragaceae & $\begin{array}{l}\text { Chrysosplenium } \\
\text { grayanum }\end{array}$ & Golden saxifrage & Whole & [138] \\
\hline Lamiaceae & Origanum vulgare & Oregano & Herba & [22] & Simaroubaceae & Ailanthus altissima & Tree of heaven & Whole & [138] \\
\hline Lamiaceae & Prunella vulgaris & Common selfheal & Whole & [73] & Tiliaceae & Tilia platyphyllos & Largeleaf linden & Whole & {$[22]$} \\
\hline Lamiaceae & Rosmarinus officinalis & Rosemary & Folium & [22] & Urticaceae & Urtica urens & Dwarf nettle & Aerial parts & [52] \\
\hline Lamiaceae & Salvia officinalis & Salvia & Folium & [22] & Zingiberaceae & $\begin{array}{l}\text { Afromomum } \\
\text { meleguetta }\end{array}$ & $\begin{array}{l}\text { Meleguetta } \\
\text { pepper }\end{array}$ & Seed & [143] \\
\hline
\end{tabular}


Table 2 Some classes of natural compounds that have been reported to inhibit pancreatic lipase activity in vitro and species from which the compound has been obtained.

\begin{tabular}{|c|c|c|c|c|}
\hline Metabolites & Scientific name & Common name & Family & References \\
\hline Flavonoids & Alpinia officinarum & Lesser galangal & Zingiberaceae & {$[144,145]$} \\
\hline Flavonoids & Taraxacum officinale & Dandelion & Asteraceae & [103] \\
\hline Flavonoids, triterpenes & Actinidia arguta & Kiwi & Actinidiaceae & [146] \\
\hline Polyphenols & Arachis hypogaea & Peanut & Fabaceae & [9] \\
\hline Polyphenols & Mangifera indica & Mango & Anacardiaceae & [9] \\
\hline Polyphenols & Medicago sativa & Alfalfa & Fabaceae & [78] \\
\hline Polyphenols & Nelumbo nucifera & Sacred lotus & Nelumbonaceae & [9] \\
\hline Polyphenols & Salacia reticulate & Kotala himbutu & Celastraceae & [101] \\
\hline Polyphenols & Salix matsudana & Corkscrew willow & Salicaceae & [147] \\
\hline $\begin{array}{l}\text { Polyphenols, proanthocyanidins, } \\
\text { catechins }\end{array}$ & Camellia sinensis & Green, black, oolong tea & Theaceae & [89] \\
\hline Polyphenols, saponins & Ilex paraguariensis & Yerba mate & Aquifoliaceae & [99] \\
\hline Proanthocyanidins & Cassia mimosoides & Nomame herba & Fabaceae & [148] \\
\hline Proanthocyanidins & Cinnamomum sieboldii & Cinnamon & Lauraceae & [86] \\
\hline Proanthocyanidins & Theobroma cacao & Cocoa & Malvaceae & [86] \\
\hline Proanthocyanidins, saponins & Vitis vinifera & Grape vine & Vitaceae & {$[79,104]$} \\
\hline Saponins & Aesculus hippocastanum & Horse chestnut & Sapindaceae & [32] \\
\hline Saponins & Aesculus turbinate & Japanese horse chestnut & Hippocastanaceae & [110] \\
\hline Saponins & Arctostaphylos uva-ursi & Bearberry & Ericaceae & {$[32]$} \\
\hline Saponins & Ardisia japonica & Marlberry & Myrsinaceae & [152] \\
\hline Saponins & Avena sativa & Oat & Poaceae & [149] \\
\hline Saponins & Coffea Arabica & Coffee & Rubiaceae & {$[32]$} \\
\hline Saponins & Cyclocarya paliurus & Wheel wingnut & Juglandaceae & [9] \\
\hline Saponins & Dioscorea nipponica & Yam & Dioscoreaceae & [9] \\
\hline Saponins & Eleutherococcus senticosus & Siberian ginseng & Araliaceae & [114] \\
\hline Saponins & Eleutherococcus sessiliflorus & Sessiloside & Araliaceae & [9] \\
\hline Saponins & Gardenia jasminoides & Cape jasmine & Rubiaceae & [118] \\
\hline Saponins & Gypsophila oldhamiana & Oldham's baby's-breath & Caryophyllaceae & [119] \\
\hline Saponins & Kochia scoparia & Burningbush & Chenopodiaceae & [150] \\
\hline Saponins & Malus domestica & Apple & Rosaceae & [32] \\
\hline Saponins & Momordica charantia & Balsampear & Cucurbitaceae & [151] \\
\hline Saponins & Olea europeae & Olive & Oleaceae & [32] \\
\hline Saponins & Panax ginseng & Ginseng & Araliaceae & [109] \\
\hline Saponins & Panax japonicus & Japanese ginseng & Araliaceae & [120] \\
\hline Saponins & Panax quinquefolium & American ginseng & Araliaceae & {$[122]$} \\
\hline Saponins & Platycodi radix & Doraji & Campanulaceae & [64] \\
\hline Saponins & Platycodon grandiflorum & Balloon flower & Campanulaceae & [103] \\
\hline Saponins & Sapindus rarak & Soapberry & Sapindaceae & [127] \\
\hline Saponins & Scabiosa tschiliensis & Pincushions & Dipsacaceae & [9] \\
\hline Saponins & Solanum lycopersicum & Tomato & Solanaceae & [32] \\
\hline Terpenes & Salvia officinalis & Salvia & Lamiaceae & [32] \\
\hline Triterpenes & Aloe vera & Aloe vera & Asphodelaceae & [32] \\
\hline Triterpenes & Betula alba & Birch & Betulaceae & [32] \\
\hline Triterpenes & Calendula officinalis & Pot marigold & Asteraceae & [32] \\
\hline Triterpenes & Melissa officinalis & Lemon balm & Lamiaceae & [32] \\
\hline Triterpenes & Origanum vulgare & Oregano & Lamiaceae & [32] \\
\hline
\end{tabular}

(rhubarb) and the combinatorial drug Chunghyuldan [72], Prunella vulgaris, Rheum palmatum, and other herbs [73]. Most of the common compounds that are found in different plant species are polyphenols, saponins, and terpenes ( 0 Table 2 ).

In the following chapters more information will be given out about the most thoroughly studied compounds, classified according to their biochemical structure.

\section{Polyphenols}

A number of studies have revealed various health benefits of plant polyphenols and their importance in foods, beverages, and natural medicine. In this context, polyphenols have some potential efficacy for preventing obesity. They inhibit enzymes related to fat metabolism including PL, lipoprotein lipase, and glycero- phosphate dehydrogenase [74]. Polyphenol extracts are able to decrease the blood levels of glucose, triglycerides, and LDL cholesterol, increase energy expenditure and fat oxidation, and reduce body weight and adiposity $[75,76]$. In fact, many polyphenols, including flavones, flavonols, tannins, and chalcones, have shown an inhibitory activity of PL $[9,22]$.

Flavonoids are a type of plant secondary metabolites that are characterized as containing two or more aromatic rings, each bearing at least one aromatic hydroxyl and connected with a carbon bridge [76]. Some of them are polymerized into large molecules, either by the plants themselves or as a result of food processing. These polymers are called tannins, and three subclasses (condensed tannins, derived tannins, and hydrolysable tannins) exhibit a variety of beneficial effects on health [76]. A flavonoid 
with PL inhibitory activity is hesperidin, obtained from the peels of Citrus unshiu [77].

Proanthocyanidins (PA), also known as condensed tannins, are the most common group of flavonoids in the Western diet. They consist of monomeric units of flavans linked through carbon-carbon and ether linkages, which are considered the second most abundant group of natural phenolics after lignins [78]. PA can be found in such common foodstuffs as cereals, legumes, fruits, vegetables, and beverages (red wine and tea in particular) $[75,79]$. They have a putative role as antioxidants, showing beneficial effects on inflammatory processes, cardiovascular diseases, and other pathological conditions $[80,81]$. For example, these compounds actively reduce plasma triglycerides by inhibiting the absorption of dietary lipids [79] and possess inhibitory effects on different digestive enzymes, such as trypsin, amylase, and lipase [36].

Some examples of polyphenols with inhibitory action on PL are proanthocyanidins from edible herbs, such as those from Cassia mimosoides [82], and tea catechins, especially (-)-catechin gallate and (-)-gallocatechin gallate, [83]. Some of the most thoroughly studied polyphenol extracts in relation to PL inhibition are the following:

Arachis hypogaea: Peanut (Arachis hypogaea) shells (hulls, seed coats), which are by-products of the peanut industry, provide several compounds showing PL inhibitory activity in a dose dependent manner $(1 \mathrm{mg} / \mathrm{mL}=42 \%$ inhibitory effect $)$ that are able to reduce body weight gain in rats fed a high-fat diet [84]. This plant contains several bioactive molecules, such as luteolin (○ Fig. 2), certain fatty acids, caffeic, ferulic, and benzoic acids, all of which are able to inhibit lipases [9]. Coumarin derivates and phenolic acids were assumed to be the major active constituents. However the authors have not examined the individual effects of each compound.

Camellia sinensis: Camellia sinensis or tea plant (green tea, black tea, or oolong tea) contains over 60 polyphenols, some of them with a potent PL inhibitory activity. It is likely the plant whose extracts have been more thoroughly used for searching new PL inhibitors. The major polyphenols are catechins ( $\bullet$ Fig. 2 ), which constitute about one-third of its total dry weight. A serving of tea is moderate to high in flavonoid and/or tannin content [85-89]. Nakai et al. [90] found that the polyphenols with more potent PL inhibitory effect were flavan-3-ol digallate esters isolated from oolong tea, such as (-)-epigallocatechin-3,5-digallate. Oolong tea-polymerized polyphenols reduced postprandial hypertriglyceridemia in olive oil-loaded rats and mice [91]. Also (-)-epigallocatechin, abundant in the green tea extract, is a weak inhibitor of $\mathrm{PL}$ and is able to decrease the postprandial hypertriglyceridemia in rodents [92].

The administration of black-tea polyphenols suppressed postprandial hypertriglyceridemia in a dose-dependent manner in rats, with theaflavin-3,3'-digallate as the most effective PL inhibitor [93], whereas other authors point out to thearubigins [94]. These extracts are able to prevent increases in body weight and adiposity in mice fed a high-fat diet [95]. The PL inhibitory and hypotriglyceridemic effects of tea extracts were corroborated by Tanaka et al. [96], who orally administered mixed fermented tea extracts and Loquat tea extracts to rats with a $10 \%$ soybean oil emulsion.

Finally, cocoa tea extract (Camellia sinensis var. ptilophylla) is rich in polyphenols with PL inhibitory effect. A single oral administration of this extract produces an inhibition of plasma triglyceride levels in olive oil-loaded ICR mice and triolein-loaded rats [97].

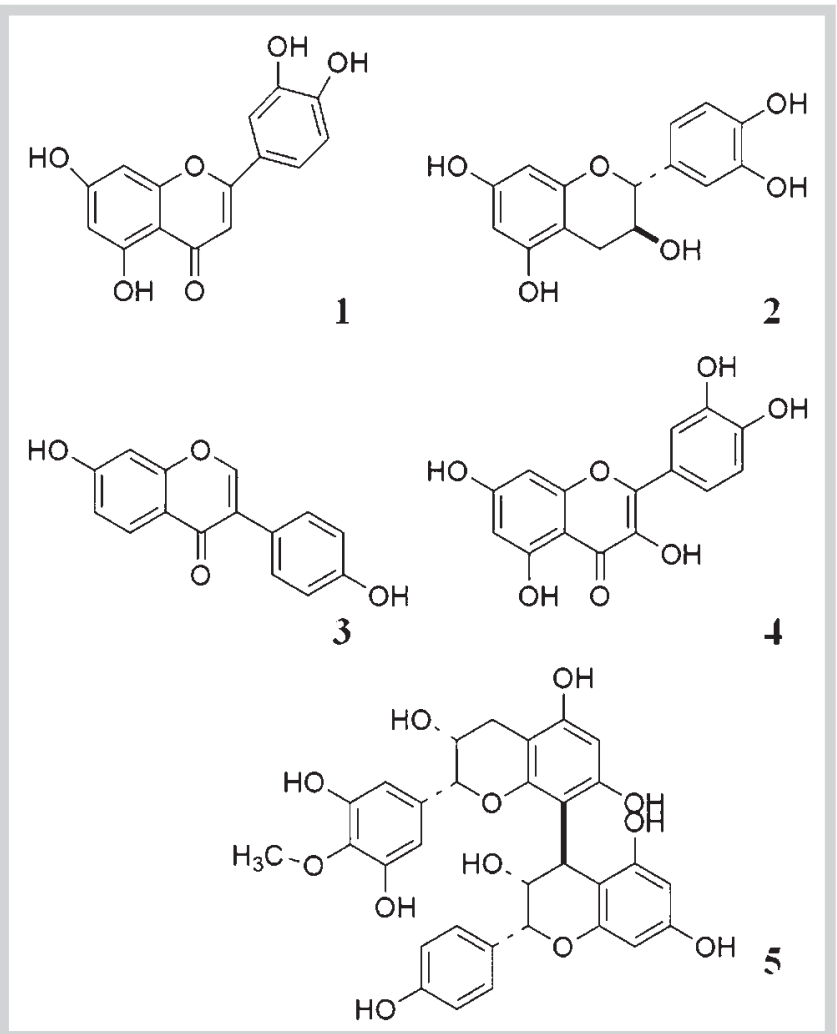

Fig. 2 Selected polyphenols with PL inhibitory activity: Luteolin (1) from Arachis hypogaea, catechin (2) from Camellia sinensis, daidzein (3) from Glycine max, quercetin (4) from Ilex paraguariensis, structure of a procyanidin (5) from Vitis vinifera.

Glycine max: Daidzein ( 0 Fig. 2 ) belongs to the group of isoflavones and is produced almost exclusively by the members of the Fabaceae/Leguminosae (bean) family such as soybean. In one study, Guo et al. [98] investigated the effects of daidzein on body weight, adipose tissue, blood, and liver lipid levels in obese mice fed a high-fat diet, finding that daidzein reduced body and white adipose tissue weights in obese mice and ameliorated the hyperlipidemia induced by the high-fat diet. The authors attributed this effect to the inhibition of PL activity and fat digestion.

Ilex paraguariensis: Yerba mate (MT) is a plant from the subtropical region of South America that is widely consumed in Brazil, Argentina, Paraguay, and Uruguay. Yerba mate contains polyphenols, such as flavonoids (quercetin and rutin) ( $\bullet$ Fig. 2) and phenolic acids (chlorogenic and caffeic acids), and is also rich in caffeine and saponins [99]. These substances act on the lipid metabolism by inhibiting PL activity in a concentration value of $1.5 \mathrm{mg} /$ $\mathrm{mL}$ [99]. Several triterpene saponins and monoterpene oligoglycosides from the leaves of yerba mate were found to exhibit potent inhibitory activity on porcine PL [100].

Malus domestica: Apples (Malus domestica) belong to the Rosaceae family whose fruits contain several phenolic substances (cholorogenic acid, catechin, epicatechin, phloridzin, and procyanins). Procyanidins in apples are mainly composed of various polymerized catechins, with some of them showing a PL inhibitory activity and reducing triglyceride absorption [36]. In corn oil-loaded mice, a single oral administration of apple polyphenols reduced plasma triglyceride levels, and a test diet containing $600 \mathrm{mg}$ of apple polyphenols significantly inhibited triglyceride 
elevation at $6 \mathrm{~h}$ after ingestion, indicating an inhibition of triglyceride absorption [36].

Salacia reticulata: Salacia reticulata contains a high concentration of polyphenols, including catechins and condensed tannins. In hot water-soluble extract from the roots of Salacia reticulata (SRHW) the concentration is about $24 \%$ polyphenols [74]. The polyphenols from Salacia reticulata inhibit enzymes related to fat metabolism, including PL, lipoprotein lipase, and glycerophosphate dehydrogenase, and are effective in preventing obesity [101]. In fact, Salacia extract markedly improved metabolic syndrome symptoms (including body weight, adiposity, glucose intolerance, hypertension, and peripheral neuropathy) in TSOD mice [102].

Taraxacum officinale: Dandelion (Taraxacum officinale) is a perennial herbaceous plant of the family Asteraceae that has been used as a phytomedicine due to its choleretic, antirhemetic, diuretic, and anti-inflammatory properties [103]. Extracts from this plant have shown hypolipidemic effects and an inhibitory activity of PL, decreasing AUC (area under curve) for the postprandial triglyceride response curve [103].

Vitis vinifera: Grapevine (Vitis vinifera) has become a model plant for studying proanthocyanidin biosynthesis. Grapevine proanthocyanidins ( $\odot$ Fig. 2) consist of two major flavan 3-ol monomers, catechin and epicatechin, that have inhibitory activity on PL $[79,104]$.

Polyphenol-rich extracts from a range of berries, particularly cloudberry, are able to inhibit PL activity in vitro, which has been attributed to their content in ellagitannins and proanthocyanidins [105].

\section{Saponins}

Saponins are a major family of secondary metabolites that occur in a wide range of plants species [106]. These compounds have been isolated from different parts of the plants, including the roots, rhizomes, stems, bark, leaves, seeds, and fruits. Occasionally, the whole plant has been used [107].

Saponins are categorized into two major classes, the triterpenoid and the steroid saponins, which are both derived from the 30 carbon atoms containing precursor oxidosqualene $[107,108]$. Some of the triterpene-rich plant materials are common foodstuffs consumed in large amounts in Mediterranean countries. Therefore, the correlation of a triterpene-rich diet and the beneficial effects of consuming a Mediterranean diet should be investigated in more detail [32]. These types of plant secondary metabolites are found to inhibit PL and, thus, may represent potential effective treatments for obesity and related disorders $[9,22]$.

Aesculus turbinata: The Japanese horse chestnut (Aesculus turbinata) is a medicinal plant widely used in East Asia. The saponin mixture extracted from the seeds is called escins and has a strong inhibitory activity on PL [110]. In mice fed a high-fat diet, total escins suppressed the increase in body weight, adiposity, and liver fat and increased triglyceride level in the feces, whereas it decreased plasma triglycerides after the oral administration of a lipid emulsion [111,112].

Dioscorea nipponica: The methanol extract of Dioscorea nipponica Makino powder has a potent inhibitory activity against porcine $\mathrm{PL}$, with an $\mathrm{IC}_{50}$ value of $5-10 \mu \mathrm{g} / \mathrm{mL}$ [66]. In fact, the saponin dioscin and its aglycone, diosgenin, both suppressed the increase of blood triacylglycerols when orally injected with corn oil to mice. Rats fed a high-fat diet containing 5\% Dioscorea nipponica Makino gained significantly less body weight and adipose tissue than control animals [66], and a similar result has been observed after

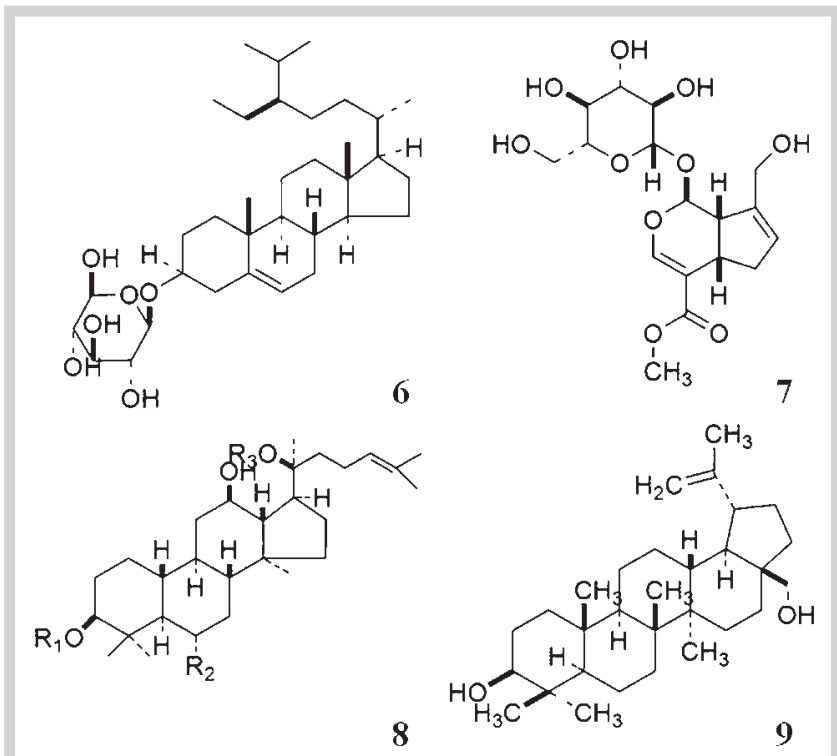

Fig. 3 Selected isoprenoids with PL inhibitory activity: Eleutheroside (6) from Eleutherococcus senticosus, geniposide (7) from Gardenia jasminoides, general structure of dammaran aglycons of ginsenosides (8) in Panax ginseng, betulin (9) from Betula alba.

administering the aqueous extract of this rhizome to mice fed a high-fat diet [113].

Eleutherococcus senticosus: Eleutherococcus senticosus is a shrub, belonging to the family Araliaceae, which is commonly distributed in north-eastern Asia. It is used as a traditional Chinese medicine against ischemic heart diseases, neurasthenia, hypertension, arthritis, and tumors [114]. At least fifteen triterpenoid saponins with in vitro PL inhibitory activity ( $\odot$ Fig. 3) have been isolated from the fruits of Eleutherococcus senticosus [115]. The total saponin fraction obtained from the fruits of Eleutherococcus senticosus exhibits inhibitory activity on PL with an $\mathrm{IC}_{50}$ value of $3.63 \mathrm{mg} / \mathrm{mL}$ [114].

Eleutherococcus sessiliflorus: Different lupine-type triterpene triglycosides isolated from a hot water extract of Eleutherococcus sessiliflorus leaves are able to inhibit PL activity in vitro and to suppress the body weight gain of mice fed a high-fat diet [116]. Gardenia jasminoides: Crocin is a glycosylated carotenoid extracted from the fructus of Gardenia jasminoides (O Fig. 3). Gardeniae Fructus is used in Asian countries as a natural colorant, and in Chinese traditional medicine for its antioxidant, cytotoxic, antitumor, and neuroprotective effects. Crocin and crocetin are effective hypolipidemic agents that act by reducing the absorption of fat and cholesterol through inhibition of PL activity [117]. Sheng et al. demonstrated that crocin selectively inhibited the activity of PL as a competitive inhibitor [118].

Gypsophila oldhamiana: Gypsophila oldhamiana (Caryophyllaceae) is a plant distributed in the north of China whose roots have high amounts of saponins, sterols, and fatty acids. The extract from this plant shows a potent inhibitory activity of PL with an $\mathrm{IC}_{50}$ value of $0.54 \mathrm{mg} / \mathrm{ml}[118,119]$ and different triterpenoid saponins, gypsosaponins $\mathrm{A}-\mathrm{C}$, as the more efficient compounds [119].

Panax ginseng: Ginseng is one of the most popular medicinal herbs and is commonly consumed as powder, a beverage, or a food supplement. Roots of Panax ginseng contain high levels of 
ginsenosides ( Fig. 3), which are steroidal saponins that show beneficial effects on lipid metabolism. Saponins from ginseng roots suppressed the expected increase in body weight and plasma triacylglycerols in mice following a high-fat diet, which was probably mediated by inhibiting PL with an $\mathrm{IC}_{50}$ value of $500 \mu \mathrm{g} /$ $\mathrm{mL}$ [109].

Panax japonicus: The rhizomes of Panax japonicus (Japanese ginseng) are used in folk medicine for the treatment of arteriosclerosis, hyperlipidemia, hypertension, and diabetes mellitus. Chikusetsusaponins prevented the increase in body weight and parametrial adipose tissue weight induced by a high-fat diet and inhibited the elevation of postprandial plasma triacylglycerols due to their inhibitory action of PL on dietary fat [120]. The delay in intestinal fat absorption was also behind the antiobesity effects observed for Korean white ginseng extract in high-fat diet-induced obese mice [121].

Panax quinquefolium: American ginseng (Panax quinquefolium) is a native plant from North America. The saponins isolated from stems and leaves of Panax quinquefolium may prevent fat storage in adipose tissue and postprandial elevations of plasma triacylglycerols by inhibiting the intestinal absorption of dietary fat through the inhibition of PL activity [122].

Platycodi grandiflorum: Platycodi radix, widely used in traditional Oriental medicines as a remedy for respiratory disorders, is rich in saponins, which are responsible for a diversity of effects including anti-inflammation, antiallergy, antitumor, and immunostimulation [64]. Given its inhibitory action on PL [123], with platycodin D as the most efficient compound [124], it ameliorated high fat-induced obesity in mice [125] and rats [64]. SK1 is an edible saponin-rich compound from Platycodi Radix that is able to reduce body weight and fat accumulation by increasing fecal lipid outputs in high-fat fed mice [126].

Sapindus rarak: The methanolic extract from the pericarps of $\mathrm{Sa}$ pindus rarak (Lerak) shows a PL inhibitory activity that is probably due to diverse saponins and sesquiterpene glycosides [127]. Scabiosa tschiliensis: Different triterpenoid saponins isolated from the Mongol and Chinese traditional medicinal herb Scabiosa tschiliensis have shown strong inhibition of PL in vitro [128]. Due to the difficult task of isolating scabiosaponins and the scarceness of this type of saponin in nature, some of them have been successfully synthesized in the laboratory [129].

Tea saponins: At least three kinds of tea (oolong, green, and black) have been used as healthy drinks. Tea saponins suppress the increases in body and parametrial adipose tissue weights and adipocyte diameters induced by a high-fat diet in mice by inhibiting PL and also reduce the elevation in plasma triacylglycerol levels after oral administration of a lipid emulsion. The Ki value of tea saponins was determined to be $0.25 \mathrm{mg} / \mathrm{mL}$ [85]. Thus, the crude saponin fraction from the flower buds of Chinese tea plant exhibits accelerating effects on gastrointestinal transit in mice and inhibitory effects against porcine PL, and three floratheasaponins $(\mathrm{A}-\mathrm{C})$ showed inhibitory effects on serum triglyceride elevation [130].

\section{Triterpenes}

Terpenes are the primary constituents of the essential oils of many types of plants and are classified by the number of terpene units in the molecule (diterpenes, triterpenes, among others). The pharmacological relevance of triterpenes has increased during the last two decades demonstrating multitarget properties such as wound healing, anti-inflammatory, antibacterial, antiviral, hepatoprotective, and antitumoral effects, combined with low toxicity [32]. Triterpene extracts are safe and provide a high potential for further pharmaceutical and pharmacological research [131], some of them inhibiting PL activity.

Betula alba: Bark of birch (Betula alba) contains pentacyclic triterpenes ( $\odot$ Fig. 3). This triterpene extract is safe and provides a high potential for further pharmaceutical and pharmacological research [32,131], displaying an inhibitory activity on PL [22].

\section{Clinical Studies about Pancreatic Lipase Inhibitors $\nabla$}

A number of plants and natural products have been screened for their PL inhibitory activity but just some of them have gone up to clinical studies. In this line, only one product derived from natural compounds (Orlistat) is currently in clinical use, although others are under investigation. Some of them are Panax ginseng [132], Camellia sinensis [133], Eleutherococcus senticosus [134], Malus domestica [135], and Arachis hypogaea [136].

In one study [132], the administration of an extract of Panax ginseng in humans for 8 weeks decreased circulating cholesterol, triglyceride, and low-density lipoprotein levels (LDL). Each subject ingested $2 \mathrm{~g}$ of Panax ginseng extract three times a day.

Lee et al. [134] reported that healthy postmenopausal women treated for 6 months with Eleutherococcus senticosus supplementation showed significant decreases in serum LDL levels and LDL/ HDL ratios.

In other study, Sugiyama et al. [135] assessed six healthy male volunteers that followed a high-fat diet with $40 \mathrm{~g}$ of fat with 10 control or 10 apple polyphenol (Malus domestica) capsules (600 or $1500 \mathrm{mg}$ ). In this study, they demonstrated that apple polyphenols may prevent obesity in humans by a PL inhibitory mechanism.

Green tea (Camellia sinensis) has been extensively studied in relation to obesity and other metabolic disorders. Thus, Chantre and Lairon [133] showed that green tea consumption may be useful to treat obesity by both, increasing thermogenesis and inhibiting PL. Thus, a green tea extract showed a direct in vitro inhibition of gastric and pancreatic lipases [133]. In moderately obese patients, green tea lowered body weight by stimulating thermogenesis and increasing energy expenditure when each subject received 2 times/d a green tea extract ( 2 capsules morning, 2 capsules midday). Ingestion of 4 capsules containing AR25 (Exolise) provided a daily total intake of $375 \mathrm{mg}$ catechins, of which $270 \mathrm{mg}$ was epigallocatechin gallate. Also, He et al. [137] administered daily $8 \mathrm{~g}$ of oolong tea for 6 weeks to 102 obese subjects. As a result, $70 \%$ of the obese subjects decreased more than $1 \mathrm{~kg}$ in body weight. In vitro studies suggested that the effect of oolong tea on body weight could be partially attributed to the inhibition of PL [68].

According to these data, a number of common herbal products that are being studied in animal ( $\odot$ Table 3 ) and human models for obesity treatment contain different metabolites that act on lipid digestion and absorption. However, it is very difficult to establish in in vivo studies whether these antiobesity effects are only or mainly due to PL activity inhibition. The clinical implications of this therapeutic approach have yet to be determined.

\section{Conclusions}

$\nabla$

Orlistat is the only drug authorized and present in Europe for the treatment of obesity within an adequate energy intake, which acts by inhibiting the lipolytic activity of PL. With the aim of find- 
Table 3 Plant extracts that showed in vivo inhibitory activity of pancreatic lipase, doses and effects. $I_{50}$ is indicated when available.

\begin{tabular}{|c|c|c|c|c|c|c|}
\hline Scientific name & Common name & $\mathrm{IC}_{50}$ & Doses & Model & Effects & References \\
\hline Aesculus turbinate & Japanese horse chestnut & $\mathrm{IC}_{50} 24 \mathrm{mg} / \mathrm{mL}$ & $0.1-0.5 \%$ of diet & DIO mice & TG plasma levels and body weight gain & [153] \\
\hline Arachis hypogaea & Peanut & $\mathrm{IC}_{50} 0.029 \mu \mathrm{g} / \mathrm{mL}$ & $1 \%$ of diet & DIO rats & Body weight gain & [136] \\
\hline Camellia sinensis & Green, black, oolong tea & $\mathrm{IC}_{50} 0.091 \mathrm{mg} / \mathrm{mL}$ & $3 \%$ of HFD & Rats & $\begin{array}{l}\text { Body weight gain } \\
\text { and visceral fat }\end{array}$ & [89] \\
\hline Cassia mimosoides & Nomame herba & $\mathrm{IC}_{50} 0.1-0.71 \mathrm{mg} / \mathrm{mL}$ & $1-3.5 \%$ of diet & $\mathrm{DIO}$ rats & Body weight gain & [154] \\
\hline Coffea arabica & Coffee & & $\begin{array}{l}0.5 \% \text { of stan- } \\
\text { dard diet }\end{array}$ & Mice & Body weight gain & [155] \\
\hline Cyclocarya paliurus & Wheel wingnut & $I_{50} 9.1 \mu \mathrm{g} / \mathrm{mL}$ & $250 \mathrm{mg} / \mathrm{kg} ; \mathrm{VO}$ & Mice & TG plasma levels and blood glucose levels & [156] \\
\hline Dioscorea nipponica & Yam & $1 C_{50} 5-10 \mathrm{mg} / \mathrm{mL}$ & $5 \%$ of HFD & Rats & TG plasma levels and body weight gain & [157] \\
\hline $\begin{array}{l}\text { Eleutherococcus senti- } \\
\text { cosus }\end{array}$ & Siberian ginseng & $\mathrm{IC}_{50} 0.22-0.29 \mathrm{mM}$ & $12 \mathrm{mg} / \mathrm{kg}$ & DIO rats & $\begin{array}{l}\text { Abdominal fat, TG in liver } \\
\text { and serum and LDL in serum }\end{array}$ & [158] \\
\hline $\begin{array}{l}\text { Eleutherococcus } \\
\text { sessiliflorus }\end{array}$ & Sessiloside & $\mathrm{IC}_{50} 0.36-0.75 \mathrm{mg} / \mathrm{mL}$ & $\begin{array}{l}100-300 \mathrm{mg} / \mathrm{kg} ; \\
\text { VO }\end{array}$ & Mice & TG plasma levels & [159] \\
\hline Gardenia jasminoides & Cape jasmine & $\mathrm{IC}_{50} 2.1 \mathrm{mg} / \mathrm{mL}$ & $50 \mathrm{mg} / \mathrm{kg} / \mathrm{d}$ & Mice & Body weight gain & [118] \\
\hline Humulus lupulus & Common hop & & $\begin{array}{l}0.2-1.2 \%(w / w) \\
\text { of extract }\end{array}$ & Mice & Body weight gain and blood glucose levels & [160] \\
\hline Ilex paraguariensis & Yerba mate & & $0.24 \%$ of HFD & Rats & Body weight gain & [99] \\
\hline Kochia scoparia & Burningbush & & $3 \%$ of HFD & Mice & Body weight gain & [150] \\
\hline Malus domestica & Apple & $\mathrm{IC}_{50} 5.6 \mu \mathrm{g} / \mathrm{mL}$ & 200 mg/kg; VO & Mice & TG plasma levels & [161] \\
\hline Myrica spp & Bayberry & & - & - & TG plasma levels & [140] \\
\hline Nelumbo nucifera & Sacred lotus & $\mathrm{IC}_{50} 0.46 \mathrm{mg} / \mathrm{mL}$ & $5 \%$ of diet & Mice & TG plasma levels and body weight gain & [162] \\
\hline Panax ginseng & Ginseng & $\mathrm{IC}_{50} 500 \mu \mathrm{g} / \mathrm{mL}$ & $\begin{array}{l}200 \mathrm{mg} / \mathrm{kg} \text { with } \\
\text { HFD }\end{array}$ & Rats & Body weight gain & [109] \\
\hline Panax japonicus & Japanese ginseng & & $1-3 \%$ of diet & DIO mice & Body weight gain & [120] \\
\hline Platycodi radix & Doraji & $\mathrm{K}_{\mathrm{i}} 0.18 \mathrm{mM}$ & $\begin{array}{l}70 \mathrm{mg} / \mathrm{kg} \text {, } \\
\text { with HFD }\end{array}$ & $\begin{array}{l}\text { Sprague } \\
\text { Dawley rats }\end{array}$ & Body weight gain & [64] \\
\hline Rhodiola rosea & Roseroot stonecrop & $\mathrm{IC}_{50} 0.093 \mathrm{mM}$ & $150 \mathrm{mg} / \mathrm{kg}$ & Mice & TG plasma levels & [141] \\
\hline Rosmarinus officinalis & Rosemary & & $200 \mathrm{mg} / \mathrm{kg} \mathrm{HFD}$ & Mice & Body weight and fat mass & [163] \\
\hline Salacia reticulata & Kotala himbutu & $I C_{50} 264 \mathrm{mg} / \mathrm{L}$ & $\begin{array}{l}125 \mathrm{mg} / \mathrm{kg} \\
\text { VO HFD }\end{array}$ & Rats & Body weight gain & [101] \\
\hline Salix matsudana & Corkscrew willow & & $5 \%$ of HFD & Wistar rats & Body weight gain & [147] \\
\hline
\end{tabular}

DIO: Diet-induced obesity; HFD: High-fat diet; VO: Via oral. (Daily food intake is approximately: rats: $20 \mathrm{~g} /$ day; mice: $4.5 \mathrm{~g} /$ day)

ing new compounds more potent or with less secondary effects than Orlistat, new natural products are being identified and screened for their PL inhibitory potential. Some of these extracts are obtained from plants that are rich in polyphenols and saponins and show inhibitory effects on fat digestion, whereas other extracts come from algae, fungi, and microorganisms. Thus, natural products provide an exciting opportunity and promise for the development of new therapeutic approaches to the treatment of obesity by blocking the digestion and absorption of dietary lipids, and constitute a valuable alternative to other pharmacological agents. Some of the products reviewed in this article show potentially promising effects for weight control. In particular apple, green tea, soybean, and ginseng seem to have great potential as sources of molecules with PL inhibitory activity. For all of them more data are needed to define effects, optimal dose required, and mechanism of action, as well as their possible side or toxic effects.

Thus, there is an urgent need to update the knowledge on the numerous natural sources that could act as inhibitors of PL in order to screen them as new potential therapeutic antiobesity agents with low secondary effects.

\section{Acknowledgements}

$\nabla$

The authors thank Línea Especial (LE/97) from the University of Navarra (Spain) and the CENIT PRONAOS Program (MICINN, Spain) for financial support. A. L. de la Garza and N. Boqué hold pre-doctoral grants from Ibercaja. We also acknowledge Marta Díaz Hernando for her contribution to the figures design.

\section{References}

1 Drew B, Dixon A, Dixon J. Obesity management: update on orlistat. Vasc Health Risk Manag 2007; 3: 817-821

2 Brug J, Crawford D. The obesity pandemic. Is it bad or worse? Eur J Public Health 2009; 19: 570-571

3 Schrauwen P, Westerterp KR. The role of high-fat diets and physical activity in the regulation of body weight. Br J Nutr 2000; 84: 417-427

4 Voshol P, Rensen PCN, van Dijk K, Romijn J, Havekes L. Effect of plasma triglyceride metabolism on lipid storage in adipose tissue: studies using genetically engineered mouse models. Biochim Biophys Acta 2009; 1791: 479-485

5 Abete I, Astrup A, Martnez JA, Thorsdottir I, Zulet M. Obesity and the metabolic syndrome: role of different dietary macronutrient distribution patterns and specific nutritional components on weight loss and maintenance. Nutr Rev 2010; 68: 214-231

6 Little T, Horowitz M, Feinle-Bisset C. Modulation by high-fat diets of gastrointestinal function and hormones associated with the regulation of energy intake: implications for the pathophysiology of obesity. Am J Clin Nutr 2007; 86: 531-541

7 Rubio M, Gargallo M, Millán A, Moreno B. Drugs in the treatment of obesity: sibutramine, orlistat and rimonabant. Public Health Nutr 2007; 10: $1200-1205$ 
8 Moreno D, Ilic N, Poulev A, Brasaemle D, Fried S, Raskin I. Inhibitory effects of grape seed extract on lipases. Nutrition 2003; 19: 876-879

9 Birari R, Bhutani K. Pancreatic lipase inhibitors from natural sources: unexplored potential. Drug Discov Today 2007; 12: 879-889

10 Sumantran $V$. Experimental approaches for studying uptake and action of herbal medicines. Phytother Res 2007; 21: 210-214

11 Yamagishi S, Matsui T, Ueda S, Fukami K, Okuda S. Clinical utility of acarbose, an alpha-glucosidase inhibitor in cardiometabolic disorders. Curr Drug Metab 2009; 10: 159-163

12 Raz I, Eldor R, Cernea S, Shafrir E. Diabetes: insulin resistance and derangements in lipid metabolism. Cure through intervention in fat transport and storage. Diabetes Metab Res 2005; 21: 3-14

13 Hosoyama H, Sugimoto A, Suzuki Y, Sakane I, Kakuda T. [Isolation and quantitative analysis of the alpha-amylase inhibitor in Lagerstroemia speciosa (L.) Pers. (Banaba)]. Yakugaku Zasshi 2003; 123: 599-605

14 Tsujita T, Takaku T, Suzuki T. Chestnut astringent skin extract, an alphaamylase inhibitor, retards carbohydrate absorption in rats and humans. J Nutr Sci Vitaminol 2008; 54: 82-88

15 Tormo MA, Gil-Exojo I, de Tejada AR, Campillo JE. White bean amylase inhibitor administered orally reduces glycaemia in type 2 diabetic rats. Br J Nutr 2006; 96: 539-544

16 Bray G, Ryan D. Drug treatment of the overweight patient. Gastroenterology 2007; 132: 2239-2252

17 McClendon K, Riche D, Uwaifo G. Orlistat: current status in clinical therapeutics. Expert Opin Drug Saf 2009; 8: 727-744

18 Weibel EK, Hadvary P, Hochuli E, Kupfer E, Lengsfeld H. Lipstatin, an inhibitor of pancreatic lipase, produced by Streptomyces toxytricini. I. Producing organism, fermentation, isolation and biological activity. J Antibiot 1987; 40: 1081-1085

19 Viner RM, Hsia Y, Tomsic T, Wong ICK. Efficacy and safety of anti-obesity drugs in children and adolescents: systematic review and meta-analysis. Obes Rev 2010; 11: 593-602

20 Heymsfield SB, Segal KR, Hauptman J, Lucas CP, Boldrin MN, Rissanen A. Effects of weight loss with orlistat on glucose tolerance and progression to type 2 diabetes in obese adults. Arch Intern Med 2000; 160: 1321-1326

21 Torgerson J, Hauptman J, Boldrin M, Sjstrm L. Xenical in the prevention of diabetes in obese subjects (XENDOS) study: a randomized study of orlistat as an adjunct to lifestyle changes for the prevention of type 2 diabetes in obese patients. Diabetes Care 2004; 27: 155-161

22 Slanc P, Doljak B, Kreft S, Lunder M, Janes D, Strukelj B. Screening of selected food and medicinal plant extracts for pancreatic lipase inhibition. Phytother Res 2009; 23: 874-877

23 Slanc P, Doljak B, Mlinaric A, Strukelj B. Screening of wood damaging fungi and macrofungi for inhibitors of pancreatic lipase. Phytother Res 2004; 18: 758-762

24 Bitou N, Ninomiya M, Tsujita T, Okuda H. Screening of lipase inhibitors from marine algae. Lipids 1999; 34: 441-445

25 Abete I, Parra MD, Zulet MA, Martinez JA. Different dietary strategies for weight loss in obesity: role of energy and macronutrient content. Nutr Rev 2006; 19: 5-17

26 Astrup A. The role of dietary fat in the prevention and treatment of obesity. Efficacy and safety of low-fat diets. Int J Obes 2001; 25: 46-50

27 Lomba A, Martinez JA, Garcia-Daz D, Paternain L, Marti A, Campion J, Milagro FI. Weight gain induced by an isocaloric pair-fed high fat diet: a nutriepigenetic study on FASN and NDUFB6 gene promoters. Mol Genet Metab 2010; 101: 273-278

28 Lomba A, Milagro FI, Garcia-Daz DF, Campion J, Marzo F, Martinez JA. A high-sucrose isocaloric pair-fed model induces obesity and impairs NDUFB6 gene function in rat adipose tissue. J Nutrigenet Nutrigenomics 2009; 2: 267-272

29 Hermsdorff HHM, Volp ACP, Bressan J. [Macronutrient profile affects diet-induced thermogenesis and energy intake]. Arch Latinoam Nutr 2007; 57: 33-42

30 Mobbs C, Mastaitis J, Yen K, Schwartz J, Mohan V, Poplawski M. Low-carbohydrate diets cause obesity, low-carbohydrate diets reverse obesity: a metabolic mechanism resolving the paradox. Appetite 2007; 48: 135-138

31 Rolls BJ. The role of energy density in the overconsumption of fat. J Nutr 2000; 130: 268-271

32 Jäger S, Trojan H, Kopp T, Laszczyk M, Scheffler A. Pentacyclic triterpene distribution in various plants - rich sources for a new group of multipotent plant extracts. Molecules 2009; 14: 2016-2031
33 Stevenson E, Astbury N, Simpson E, Taylor M, Macdonald I. Fat oxidation during exercise and satiety during recovery are increased following a low-glycemic index breakfast in sedentary women. J Nutr 2009; 139: 890-897

34 Armand $M$. Lipases and lipolysis in the human digestive tract: where do we stand? Curr Opin Clin Nutr Metab Care 2007; 10: 156-164

35 Lowe $M$. The triglyceride lipases of the pancreas. J Lipid Res 2002; 43: 2007-2016

36 Sugiyama H, Akazome Y, Shoji T, Yamaguchi A, Yasue M, Kanda T. Oligomeric procyanidins in apple polyphenol are main active components for inhibition of pancreatic lipase and triglyceride absorption. J Agric Food Chem 2007; 55: 4604-4609

37 Neovius M, Johansson K, Rssner S. Head-to-head studies evaluating efficacy of pharmaco-therapy for obesity: a systematic review and metaanalysis. Obes Rev 2008; 9: 420-427

38 Filippatos T, Derdemezis C, Gazi I, Nakou E, Mikhailidis D, Elisaf M. Orlistat-associated adverse effects and drug interactions: a critical review. Drug Saf 2008; 31: 53-65

39 Kopelman P, Bryson A, Hickling R, Rissanen A, Rossner S, Toubro S. Cetilistat (ATL-962), a novel lipase inhibitor: a 12-week randomized, placebo-controlled study of weight reduction in obese patients. Int J Obes 2007; 31: 494-499

40 Melia AT, Koss-Twardy SG, Zhi J. The effect of orlistat, an inhibitor of dietary fat absorption, on the absorption of vitamins $\mathrm{A}$ and $\mathrm{E}$ in healthy volunteers. J Clin Pharmacol 1996; 36: 647-653

41 Mutoh M, Nakada N, Matsukuma S, Ohshima S, Yoshinari K, Watanabe J. Panclicins, novel pancreatic lipase inhibitors. I. Taxonomy, fermentation, isolation and biological activity. J Antibiot 1994; 47: 1369-1375

42 Nonaka Y, Ohtaki H, Ohtsuka E, Kocha T, Fukuda T, Takeuchi T. Effects of ebelactone B, a lipase inhibitor, on intestinal fat absorption in the rat. J Enzym Inhib 1996; 10: 57-63

43 Liu D, Wang F, Liao T, Tang J, Steglich W, Zhu H. Vibralactone: a lipase inhibitor with an unusual fused beta-lactone produced by cultures of the basidiomycete Boreostereum vibrans. Org Lett 2006; 8: 5749-5752

44 Weber HK, Zuegg J, Faber K, Pleiss J. Molecular reasons for lipase-sensitivity against acetaldehyde. J Mol Catal B 1997: 131-138

45 Mizutani T, Inatomi S, Inazu A, Kawahara E. Hypolipidemic effect of Pleurotus eryngii extract in fat-loaded mice. J Nutr Sci Vitaminol 2010; 56: $48-53$

46 Lee J, Song J, Lee J. Optimal extraction conditions of anti-obesity lipase inhibitor from Phellinus linteus and nutritional characteristics of the extracts. Mycobiology 2010; 38: 58-61

47 Kim J, Kim H, Park H, Youn S, Choi D, Shin C. Development of inhibitors against lipase and alpha-glucosidase from derivatives of monascus pigment. FEMS Microbiol Lett 2007; 276: 93-98

48 Jones A, Gu L, Sorrels C, Sherman D, Gerwick W. New tricks from ancient algae: natural products biosynthesis in marine cyanobacteria. Curr Opin Chem Biol 2009; 13: 216-223

49 Bitou N, Ninomiya M, Tsujita T, Okuda H. Screening of lipase inhibitors from marine algae. Lipids 1999; 34: 441-445

50 Ben Rebah F, Smaoui S, Frikha F, Gargouri Y, Miled N. Inhibitory effects of tunisian marine algal extracts on digestive lipases. Appl Biochem Biotechnol 2008; 151: 71-79

51 Matsumoto M, Hosokawa M, Matsukawa N, Hagio M, Shinoki A, Nishimukai M. Suppressive effects of the marine carotenoids, fucoxanthin and fucoxanthinol on triglyceride absorption in lymph duct-cannulated rats. Eur J Nutr 2010; 49: 243-249

52 Gholamhoseinian A, Shahouzehi B, Sharifi-far F. Inhibitory effect of some plant extracts on pancreatic lipase. Int J Pharmacol 2010; 6: 1824

53 Gargouri Y, Julien R, Pieroni G, Verger R, Sarda L. Studies on the inhibition of pancreatic and microbial lipases by soybean proteins. J Lipid Res 1984; 25: 1214-1221

54 Lairon D, Lafont H, Vigne JL, Nalbone G, Lonardi J, Hauton JC. Effects of dietary fibers and cholestyramine on the activity of pancreatic lipase in vitro. Am J Clin Nutr 1985; 42: 629-638

55 Tsujita T, Matsuura Y, Okuda H. Studies on the inhibition of pancreatic and carboxylester lipases by protamine. J Lipid Res 1996; 37: 14811487

56 Tsujita T, Sumiyoshi M, Takaku T, Momsen W, Lowe M, Brockman H. Inhibition of lipases by epsilon-polylysine. J Lipid Res 2003; 44: 22782286 
57 Ivanova M, Panaiotov I, Bois A, GArgouri Y, Verger R. Inhibitiion of pancreatic lipase by ovalbumin and -lactoglobulin A at the air-water interface. J Colloid Interface Sci 1990; 136: 363-374

58 Gargouri Y, Julien R, Sugihara A, Verger R, Sarda L. Inhibition of pancreatic and microbial lipases by proteins. Biochim Biophys Acta 1984; 795: 326-331

59 Han LK, Kimura Y, Okuda H. Reduction in fat storage during chitin-chitosan treatment in mice fed a high-fat diet. Int J Obes 1999; 23: 174179

60 Tsujita T, Takaichi H, Takaku T, Sawai T, Yoshida N, Hiraki J. Inhibition of lipase activities by basic polysaccharide. J Lipid Res 2007; 48: 358-365

61 Knuckles $B$. Effect of phytate and other myo-inositol phosphate esters on lipase activity. J Food Sci 1988; 53: 250-252

62 Raghavendra MP, Prakash V. Phenylboronic acid-a potent inhibitor of lipase from Oryza sativa. J Agric Food Chem 2002; 50: 6037-6041

63 Ninomiya K, Matsuda H, Shimoda H, Nishida N, Kasajima N, Yoshino T. Carnosic acid, a new class of lipid absorption inhibitor from sage. Bioorg Med Chem Lett 2004; 14: 1943-1946

64 Zhao HL, Sim J, Shim SH, Ha YW, Kang SS, Kim YS. Antiobese and hypolipidemic effects of platycodin saponins in diet-induced obese rats: evidences for lipase inhibition and calorie intake restriction. Int J Obes 2005; 29: 983-990

65 Zhao H, Kim Y. Determination of the kinetic properties of platycodin D for the inhibition of pancreatic lipase using a 1,2-diglyceride-based colorimetric assay. Arch Pharm Res 2004; 27: 1048-1052

66 Kwon C, Sohn H, Kim S, Kim J, Son K, Lee J. Anti-obesity effect of Dioscorea nipponica Makino with lipase-inhibitory activity in rodents. Biosci Biotechnol Biochem 2003; 67: 1451-1456

67 Won S, Kim S, Kim Y, Lee P, Ryu J, Kim J. Licochalcone A: a lipase inhibitor from the roots of Glycyrrhiza uralensis. Food Res Int 2007; 40: 10461050

68 Ono Y, Hattori E, Fukaya Y, Imai S, Ohizumi Y. Anti-obesity effect of Nelumbo nucifera leaves extract in mice and rats. J Ethnopharmacol 2006; 106: 238-244

$69 \mathrm{Kim} \mathrm{H}$, Kang M. Screening of Korean medicinal plants for lipase inhibitory activity. PTR. Phytother Res 2005; 19: 359-361

70 Moreno D, Ripoll C, Ilic N, Poulev A, Aubin C, Raskin I. Inhibition of lipid metabolic enzymes using Mangifera indica extracts. J Food Agric Environ 2006; 4: 21-26

71 Lei F, Zhang XN, Wang W, Xing DM, Xie WD, Su H. Evidence of anti-obesity effects of the pomegranate leaf extract in high-fat diet induced obese mice. Int J Obes 2007; 31: 1023-1029

72 Yang H, Kim Y, Bae H, Cho K, Shin J, Kim N, Kim D. Rhei Rhizoma and Chunghyuldan inhibit pancreatic lipase. Nat Prod Sci 2003; 9: 38-43

73 Zheng C, Duan Y, Gao J, Ruan Z. Screening for anti-lipase properties of 37 traditional Chinese medicinal herbs. J Chin Med Assoc 2010; 73 319-324

74 Yoshikawa M, Shimoda H, Nishida N, Takada M, Matsuda H. Salacia reticulata and its polyphenolic constituents with lipase inhibitory and lipolytic activities have mild antiobesity effects in rats. J Nutr 2002; 132: 1819-1824

75 Terra X, Montagut G, Bustos M, Llopiz N, Ardvol A, Blad C. Grape-seed procyanidins prevent low-grade inflammation by modulating cytokine expression in rats fed a high-fat diet. J Nutr Biochem 2009; 20: 210218

76 García-Lafuente A, Guillamón E, Villares A, Rostagno M, Martínez J. Flavonoids as anti-inflammatory agents: implications in cancer and cardiovascular disease. Inflamm Res 2009; 58: 537-552

77 Kawaguchi K, Mizuno T, Aida K, Uchino K. Hesperidin as an inhibitor of lipases from porcine pancreas and Pseudomonas. Biosci Biotechnol Biochem 1997; 61: 102-104

78 He F, Pan $\mathrm{Q}$ Shi Y, Duan C. Biosynthesis and genetic regulation of proanthocyanidins in plants. Molecules 2008; 13: 2674-2692

79 Quesada H, del Bas JM, Pajuelo D, Daz S, Fernandez-Larrea J, Pinent M. Grape seed proanthocyanidins correct dyslipidemia associated with a high-fat diet in rats and repress genes controlling lipogenesis and VLDL assembling in liver. Int J Obes 2009; 33: 1007-1012

80 Lee Y, Cho E, Tanaka T, Yokozawa T. Inhibitory activities of proanthocyanidins from persimmon against oxidative stress and digestive enzymes related to diabetes. J Nutr Sci Vitaminol 2007; 53: 287-292

81 de la Iglesia R, Milagro FI, Campion J, Boque N, Martinez JA. Healthy properties of proanthocyanidins. Biofactors 2010; 36: 159-168

82 Yamamoto M, Shimura S, Itoh Y, Ohsaka T, Egawa M, Inoue S. Anti-obesity effects of lipase inhibitor CT-II, an extract from edible herbs, Nomame Herba, on rats fed a high-fat diet. Int J Obes 2000; 24: 758-764
83 Ikeda I, Tsuda K, Suzuki Y, Kobayashi M, Unno T, Tomoyori H. Tea catechins with a galloyl moiety suppress postprandial hypertriacylglycerolemia by delaying lymphatic transport of dietary fat in rats. J Nutr 2005; 135: 155-159

84 Moreno D, Ilic N, Poulev A, Raskin I. Effects of Arachis hypogaea nutshell extract on lipid metabolic enzymes and obesity parameters. Life Sci 2006; 78: 2797-2803

85 Han LK, Kimura Y, Kawashima M, Takaku T, Taniyama T, Hayashi T. Anti-obesity effects in rodents of dietary teasaponin, a lipase inhibitor. Int J Obes 2001; 25: 1459-1464

86 Tanaka T, Matsuo Y, Kouno I. Chemistry of secondary polyphenols produced during processing of tea and selected foods. Int J Mol Sci 2009; 11: 14-34

$87 \mathrm{Koo} \mathrm{S,} \mathrm{Noh} \mathrm{S.} \mathrm{Green} \mathrm{tea} \mathrm{as} \mathrm{inhibitor} \mathrm{of} \mathrm{the} \mathrm{intestinal} \mathrm{absorption} \mathrm{of} \mathrm{lip-}$ ids: potential mechanism for its lipid-lowering effect. J Nutr Biochem 2007; 18: 179-183

88 Juhel C, Armand M, Pafumi Y, Rosier C, Vandermander J, Lairon D. Green tea extract (AR25) inhibits lipolysis of triglycerides in gastric and duodenal medium in vitro. J Nutr Biochem 2000; 11: 45-51

89 Bose M, Lambert J, Ju J, Reuhl K, Shapses S, Yang C. The major green tea polyphenol, (-)-epigallocatechin-3-gallate, inhibits obesity, metabolic syndrome, and fatty liver disease in high-fat-fed mice. J Nutr 2008; 138: 1677-1683

90 Nakai M, Fukui Y, Asami S, Toyoda-Ono Y, Iwashita T, Shibata H. Inhibitory effects of oolong tea polyphenols on pancreatic lipase in vitro. J Agric Food Chem 2005; 53: 4593-4598

91 Toyoda-Ono Y, Yoshimura M, Nakai M, Fukui Y, Asami S, Shibata H. Suppression of postprandial hypertriglyceridemia in rats and mice by oolong tea polymerized polyphenols. Biosci Biotechnol Biochem 2007; 71: 971-976

92 Ikeda I. Multifunctional effects of green tea catechins on prevention of the metabolic syndrome. Asia Pac J Clin Nutr 2008; 17: 273-274

93 Kobayashi M, Ichitani M, Suzuki Y, Unno T, Sugawara T, Yamahira T. Black-tea polyphenols suppress postprandial hypertriacylglycerolemia by suppressing lymphatic transport of dietary fat in rats. J Agric Food Chem 2009; 57: 7131-7136

94 Kusano R, Andou H, Fujieda M, Tanaka T, Matsuo Y, Kouno I. Polymerlike polyphenols of black tea and their lipase and amylase inhibitory activities. Chem Pharm Bull 2008; 56: 266-272

95 Uchiyama S, Taniguchi Y, Saka A, Yoshida A, Yajima H. Prevention of diet-induced obesity by dietary black tea polyphenols extract in vitro and in vivo. Nutrition 2011; 27: 287-292

96 Tanaka K, Tamaru S, Nishizono S, Miyata Y, Tamaya K, Matsui T. Hypotriacylglycerolemic and antiobesity properties of a new fermented tea product obtained by tea-rolling processing of third-crop green tea (Camellia sinensis) leaves and Loquat (Eriobotrya japonica) leaves. Biosci Biotechnol Biochem 2010; 74: 1606-1612

97 Kurihara H, Shibata H, Fukui Y, Kiso Y, Xu J, Yao X. Evaluation of the hypolipemic property of Camellia sinensisvar. ptilophylla on postprandial hypertriglyceridemia. J Agric Food Chem 2006; 54: 4977-4981

98 Guo Y, Wu G, Su X, Yang H, Zhang J. Antiobesity action of a daidzein derivative on male obese mice induced by a high-fat diet. Nutr Res 2009; 29: 656-663

99 Martins F, Noso T, Porto V, Curiel A, Gambero A, Bastos DHM. Maté tea inhibits in vitro pancreatic lipase activity and has hypolipidemic effect on high-fat diet-induced obese mice. Obesity 2010; 18: 42-47

100 Sugimoto S, Nakamura S, Yamamoto S, Yamashita C, Oda Y, Matsuda H. Brazilian natural medicines. III. structures of triterpene oligoglycosides and lipase inhibitors from mate, leaves of Ilex paraguariensis. Chem Pharm Bull 2009; 57: 257-261

101 Yoshikawa M, Shimoda H, Nishida N, Takada M, Matsuda H. Salacia reticulata and its polyphenolic constituents with lipase inhibitory and lipolytic activities have mild antiobesity effects in rats. J Nutr 2002; 132: 1819-1824

102 Akase T, Shimada T, Harasawa Y, Akase T, Ikeya Y, Nagai E. Preventive effects of Salacia reticulata on obesity and metabolic disorders in TSOD mice. Evid Based Complement Alternat Med, advance online publication 8 June 2009; doi: 10.1093/ecam/nep052

103 Zhang J, Kang M, Kim M, Kim M, Song J, Lee Y. Pancreatic lipase inhibitory activity of Taraxacum officinale in vitro and in vivo. Nutr Res Pract 2008; 2: 200-203

104 Zhao J, Pang Y, Dixon R. The mysteries of proanthocyanidin transport and polymerization. Plant Physiol 2010; 153: 1-18

105 McDougall GJ, Kulkarni NN, Stewart D. Berry polyphenols inhibit pancreatic lipase activity in vitro. J Food Chem 2009; 115: 193-199 
106 Sparg SG, Light ME, van Staden J. Biological activities and distribution of plant saponins. J Ethnopharmacol 2004; 94: 219-243

107 Vincken J, Heng L, de Groot A, Gruppen H. Saponins, classification and occurrence in the plant kingdom. Phytochemistry 2007; 68: 275-297

108 Haralampidis $K$, Trojanowska M, Osbourn A. Biosynthesis of triterpenoid saponins in plants. Adv Biochem Eng Biotechnol 2002; 75: 31

109 Karu N, Reifen R, Kerem Z. Weight gain reduction in mice fed Panax ginseng saponin, a pancreatic lipase inhibitor. J Agric Food Chem 2007; 55: 2824-2828

110 Kimura H, Ogawa S, Jisaka M, Kimura Y, Katsube T, Yokota K. Identification of novel saponins from edible seeds of Japanese horse chestnut (Aesculus turbinata Blume) after treatment with wooden ashes and their nutraceutical activity. J Pharm Biomed Anal 2006; 41: 16571665

111 Hu J, Zhu X, Han L, Saito M, Sun Y, Yoshikawa M. Anti-obesity effects of escins extracted from the seeds of Aesculus turbinata BLUME (Hippocastanaceae). Chem Pharm Bull 2008; 56: 12-16

112 Kimura H, Ogawa S, Katsube T, Jisaka M, Yokota K. Antiobese effects of novel saponins from edible seeds of Japanese horse chestnut (Aesculus turbinata BLUME) after treatment with wood ashes. J Agric Food Chem 2008; 56: 4783-4788

113 Song M, Lv N, Kim E, Kwon K, Yoo Y, Kim J. Antiobesity activity of aqueous extracts of Rhizoma Dioscoreae tokoronis on high-fat diet-induced obesity in mice. J Med Food 2009; 12: 304-309

114 Li F, Li W, Fu H, Zhang Q Koike K. Pancreatic lipase-inhibiting triterpenoid saponins from fruits of Acanthopanax senticosus. Chem Pharm Bull 2007; 55: 1087-1089

115 Jiang W, Li W, Han L, Liu L, Zhang $Q$ Z Zhang S. Biologically active triterpenoid saponins from Acanthopanax senticosus. J Nat Prod 2006; 69: 1577-1581

116 Yoshizumi K, Hirano K, Ando H, Hirai Y, Ida Y, Tsuji T. Lupane-type saponins from leaves of Acanthopanax sessiliflorus and their inhibitory activity on pancreatic lipase. J Agric Food Chem 2006; 54: 335-341

117 Lee I, Lee J, Baek N, Kim D. Antihyperlipidemic effect of crocin isolated from the fructus of Gardenia jasminoides and its metabolite Crocetin. Biol Pharm Bull 2005; 28: 2106-2110

118 Sheng L, Qian Z, Zheng S, Xi L. Mechanism of hypolipidemic effect of crocin in rats: crocin inhibits pancreatic lipase. Eur J Pharmacol 2006; 543: 116-122

119 Zheng Q Li W, Han L, Koike K. Pancreatic lipase-inhibiting triterpenoid saponins from Gypsophila oldhamiana. Chem Pharm Bull 2007; 55: 646-650

120 Han L, Zheng Y, Yoshikawa M, Okuda H, Kimura Y. Anti-obesity effects of chikusetsusaponins isolated from Panax japonicus rhizomes. BMC Complement Alternat Med 2005; 5: 9

121 Lee Y, Cha B, Yamaguchi K, Choi S, Yonezawa T, Teruya T. Effects of Korean white ginseng extracts on obesity in high-fat diet-induced obese mice. Cytotechnology 2010; 62: 367-376

122 Liu W, Zheng Y, Han L, Wang H, Saito M, Ling M. Saponins (Ginsenosides) from stems and leaves of Panax quinquefolium prevented high-fat diet-induced obesity in mice. Phytomedicine 2008; 15 : $1140-1145$

123 Xu B, Han L, Zheng Y, Lee J, Sung C. In vitro inhibitory effect of triterpenoidal saponins from Platycodi Radix on pancreatic lipase. Arch Pharm Res 2005; 28: 180-185

124 Zhao H, Kim Y. Determination of the kinetic properties of platycodin D for the inhibition of pancreatic lipase using a 1,2-diglyceride-based colorimetric assay. Arch Pharm Res 2004; 27: 968-972

125 Han L, Zheng Y, Xu B, Okuda H, Kimura Y. Saponins from platycodi radix ameliorate high fat diet-induced obesity in mice. J Nutr 2002; 132: 2241-2245

126 Kim J, Moon K, Seo K, Park K, Choi M, Do G. Supplementation of SK1 from Platycodi radix ameliorates obesity and glucose intolerance in mice fed a high-fat diet. J Med Food 2009; 12: 629-636

127 Morikawa T, Xie Y, Asao Y, Okamoto M, Yamashita C, Muraoka O. Oleanane-type triterpene oligoglycosides with pancreatic lipase inhibitory activity from the pericarps of Sapindus rarak. Phytochemistry 2009; 70: 1166-1172

128 Zheng $Q$ Koike K, Han L, Okuda H, Nikaido T. New biologically active triterpenoid saponins from Scabiosa tschiliensis. J Nat Prod 2004; 67: 604-613

129 Guo T, Liu Q Wang P, Zhang L, Zhang W, Li Y. Facile synthesis of three bidesmosidic oleanolic acid saponins with strong inhibitory activity on pancreatic lipase. Carbohydr Res 2009; 344: 1167-1174
130 Yoshikawa M, Morikawa T, Yamamoto K, Kato Y, Nagatomo A, Matsuda $H$. Floratheasaponins A-C, acylated oleanane-type triterpene oligoglycosides with anti-hyperlipidemic activities from flowers of the tea plant (Camellia sinensis). J Nat Prod 2005; 68: 1360-1365

131 Jäger S, Laszczyk M, Scheffler A. A preliminary pharmacokinetic study of betulin, the main pentacyclic triterpene from extract of outer bark of birch (Betulae alba cortex). Molecules 2008; 13: 3224-3235

132 Kim S, Park K. Effects of Panax ginseng extract on lipid metabolism in humans. Pharmacol Res 2003; 48: 511-513

133 Chantre P, Lairon D. Recent findings of green tea extract AR25 (Exolise) and its activity for the treatment of obesity. Phytomedicine 2002; 9: 3-8

134 Lee Y, Chung H, Kwak H, Yoon S. The effects of A. senticosus supplementation on serum lipid profiles, biomarkers of oxidative stress, and lymphocyte DNA damage in postmenopausal women. Biochem Biophys Res Commun 2008; 375: 44-48

135 Sugiyama H, Akazome Y, Shoji T, Yamaguchi A, Yasue M, Kanda T. Oligomeric procyanidins in apple polyphenol are main active components for inhibition of pancreatic lipase and triglyceride absorption. J Agric Food Chem 2007; 55: 4604-4609

136 Moreno D, Ilic N, Poulev A, Raskin I. Effects of Arachis hypogaea nutshell extract on lipid metabolic enzymes and obesity parameters. Life Sci 2006; 78: 2797-2803

137 He R, Chen L, Lin B, Matsui Y, Yao X, Kurihara H. Beneficial effects of oolong tea consumption on diet-induced overweight and obese subjects. Chin J Integr Med 2009; 15: 34-41

138 Sharma N, Sharma V, Seo S. Screening of some medicinal plants for anti-lipase activity. J Ethnopharmacol 2005; 97: 453-456

139 Möller N, Roos N, Schrezenmeir J. Lipase inhibitory activity in alcohol extracts of worldwide occurring plants and propolis. Phytother Res 2009; 23: 585-586

140 Kobayashi K, Ihara S, Kobata A, Itoh K, Kusunoki N, Yoshizaki F. Inhibitory effect of Myrica bark on lipase activity in mouse plasma and gastrointestinal tract. J Med Food 2008; 11: 289-293

141 Kobayashi K, Yamada K, Murata T, Hasegawa T, Takano F, Koga K. Constituents of Rhodiola rosea showing inhibitory effect on lipase activity in mouse plasma and alimentary canal. Planta Med 2008; 74: 17161719

142 Birari R, Roy S, Singh A, Bhutani K. Pancreatic lipase inhibitory alkaloids of Murraya koenigii leaves. Nat Prod Commun 2009; 4: 10891092

143 Ekanem AP, Wang M, Simon JE, Moreno DA. Antiobesity properties of two African plants (Afromomum meleguetta and Spilanthes acmella) by pancreatic lipase inhibition. Phytother Res 2007; 21: 1253-1255

144 Shin J, Han M, Song M, Baek N, Kim D. 5-Hydroxy-7-(4'-hydroxy-3'methoxyphenyl)-1-phenyl-3-heptanone: a pancreatic lipase inhibitor isolated from Alpinia officinarum. Biol Pharm Bull 2004; 27: 138140

145 Shin J, Han M, Kim D. 3-Methylethergalangin isolated from Alpinia officinarum inhibits pancreatic lipase. Biol Pharm Bull 2003; 26: 854857

146 Jang D, Lee G, Kim J, Lee Y, Kim J, Kim Y. A new pancreatic lipase inhibitor isolated from the roots of Actinidia arguta. Arch Pharm Res 2008; 31: 666-670

147 Han L, Sumiyoshi M, Zhang J, Liu M, Zhang X, Zheng Y. Anti-obesity action of Salix matsudana leaves (Part 1). Anti-obesity action by polyphenols of Salix matsudana in high fat-diet treated rodent animals. Phytother Res 2003; 17: 1188-1194

148 Tucci SA, Boyland EJ, Halford JC. The role of lipid and carbohydrate digestive enzyme inhibitors in the management of obesity: a review of current and emerging therapeutic agents. Diabetes Metab Syndr Obes 2010; 3: 125-143

149 Osbourn A. Saponins in cereals. Phytochemistry 2003; 62: 1-4

150 Han L, Nose R, Li W, Gong X, Zheng Y, Yoshikawa M. Reduction of fat storage in mice fed a high-fat diet long term by treatment with saponins prepared from Kochia scoparia fruit. Phytother Res 2006; 20: 877-882

151 Oishi Y, Sakamoto T, Udagawa H, Taniguchi H, Kobayashi-Hattori K, Ozawa $Y$. Inhibition of increases in blood glucose and serum neutral fat by Momordica charantia saponin fraction. Biosci Biotechnol Biochem 2007; 71: 735-740

152 Chang X, Li W, Jia Z, Satou T, Fushiya S, Koike K. Biologically active triterpenoid saponins from Ardisia japonica. J Nat Prod 2007; 70: 179187 
153 Kimura H, Ogawa S, Katsube T, Jisaka M, Yokota K. Antiobese effects of novel saponins from edible seeds of Japanese horse chestnut (Aesculus turbinata BLUME) after treatment with wood ashes. J Agric Food Chem 2008; 56: 4783-4788

154 Yamamoto M, Shimura S, Itoh Y, Ohsaka T, Egawa M, Inoue S. Anti-obesity effects of lipase inhibitor CT-II, an extract from edible herbs, Nomame Herba, on rats fed a high-fat diet. Int J Obes 2000; 24: 758-764

155 Shimoda H, Seki E, Aitani M. Inhibitory effect of green coffee bean extract on fat accumulation and body weight gain in mice. BMC Complement Alternat Med 2006; 6: 9

156 Kurihara H, Asami S, Shibata H, Fukami H, Tanaka T. Hypolipemic effect of Cyclocarya paliurus (Batal) Iljinskaja in lipid-loaded mice. Biol Pharm Bull 2003; 26: 383-385

157 Kwon C, Sohn H, Kim S, Kim J, Son K, Lee J. Anti-obesity effect of Dioscorea nipponica Makino with lipase-inhibitory activity in rodents. Biosci Biotechnol Biochem 2003; 67: 1451-1456

158 Cha Y, Rhee S, Heo Y. Acanthopanax senticosus extract prepared from cultured cells decreases adiposity and obesity indices in C57BL/6] mice fed a high fat diet. J Med Food 2004; 7: 422-429
159 Yoshizumi K, Murota K, Watanabe S, Tomi H, Tsuji T, Terao J. Chiisanoside is not absorbed but inhibits oil absorption in the small intestine of rodents. Biosci Biotechnol Biochem 2008; 72: 1126-1129

160 Yajima H, Noguchi T, Ikeshima E, Shiraki M, Kanaya T, Tsuboyama-Kasaoka $\mathrm{N}$. Prevention of diet-induced obesity by dietary isomerized hop extract containing isohumulones, in rodents. Int J Obes 2005; 29: 991-997

161 Sugiyama H, Akazome Y, Shoji T, Yamaguchi A, Yasue M, Kanda T. Oligomeric procyanidins in apple polyphenol are main active components for inhibition of pancreatic lipase and triglyceride absorption. J Agric Food Chem 2007; 55: 4604-4609

162 Ono Y, Hattori E, Fukaya Y, Imai S, Ohizumi Y. Anti-obesity effect of Nelumbo nucifera leaves extract in mice and rats. J Ethnopharmacol 2006; 106: 238-244

163 Harach T, Aprikian O, Monnard I, Moulin J, Membrez M, Bolor J. Rosemary (Rosmarinus officinalis L.) leaf extract limits weight gain and liver steatosis in mice fed a high-fat diet. Planta Med 2010; 76: 566-571 